\title{
Brazilian Companies' Dividend Payout in a Political Uncertainty Scenario
}

\author{
Willian Marques Peixoto, Michele Nascimento Jucá \\ Mackenzie Presbiterian University, São Paulo, Brazil \\ Email: willianmpeixoto@gmail.com, michele.juca@mackenzie.br
}

How to cite this paper: Peixoto, W. M., \& Jucá, M. N. (2021). Brazilian Companies' Dividend Payout in a Political Uncertainty Scenario. Open Journal of Business and Management, 9, 1585-1602. https://doi.org/10.4236/ojbm.2021.94086

Received: June 5, 2021

Accepted: July 2, 2021

Published: July 5, 2021

Copyright (c) 2021 by author(s) and Scientific Research Publishing Inc. This work is licensed under the Creative Commons Attribution International License (CC BY 4.0).

http://creativecommons.org/licenses/by/4.0/ (c) (i) Open Access

\begin{abstract}
The analysis of the determinants of the dividend payout policy becomes even more relevant in a context of crisis. In this scenario, companies wonder which strategy shall prevail-either to keep the payout ratio constancy to signal to the market positive aspects about themselves or to adapt it to the external conjuncture, protecting themselves from future uncertainties. This being so, this study aims at identifying the determinants of the dividend payout policy, in the period before and after the former President Dilma Rousseffs impeachment, by using logarithmic and probabilistic regression models. To this end, a sample of Brazilian non-financial publicly-held companies is considered, whose data are obtained from the Capital IQ base. As a result, the corporate dividend policy is identified as not being affected by the market environment. Such a fact indicates that Brazilian companies choose to maintain their dividend payout policy, even in scenarios of political uncertainty. This study differs from the others for analyzing the relationship between dividend payout decisions, whether in times of stability or in political and economic crisis.
\end{abstract}

\section{Keywords}

Dividend Policy, Political Crisis, Impeachment, Logistic Regression

\section{Introduction}

Among the main corporate decisions are financing, investment and dividend payout policy. Determining the ideal level of profit distribution as well as the amount of capital to be retained and reinvested in the company impact other decisions (Barros et al., 2020). The dividend payout theory is controversial. For Miller and Modigliani (1961), the company's value is not affected by the dividend payout, but rather by its capacity to generate value and risk from its assets. For others, dividend payout policy is relevant. 
According to Gordon $(1959,1963)$ and Lintner (1962), the dividend payout increases the share price and, therefore, the shareholders' wealth. Thus, investors prefer to receive dividends as soon as possible, reducing the return uncertainty on their investment, which ends up by raising the share price. However, its excessive distribution implies a reduction in the amounts invested, which compromises the companies' investment potential and growth in the long run.

According to Driver et al. (2020), financial models tested under conditions of perfect financial markets minimize conflicts and the importance of the dividend payout policy. However, it happens that in the real world-of imperfect markets-issues such as information asymmetry and pecking order (Myers \& Majluf, 1984), trade-off (Kraus \& Litzenberger, 1973), signaling (Ross, 1977), agency problems (Jensen \& Meckling, 1976; Jensen, 1986), taxes and transaction costs (Myers, 1984; Fischer et al., 1989) make the topic even more relevant.

In addition to these frictions, other variables of a macroeconomic nature impact the dividend payout, including economic and political crises (Attig et al., 2021). For Latham and Braun (2011), economic crises are the most transformative events faced by organizations. This fact stems from their unexpected appearance and the absence of a defined duration period. Despite the negative impact and recurrence of these events of uncertainty, the author states that there is little research on their impact on corporate decisions. In turn, for Lim (2016), economic crises have caused a reduction in companies' dividend payout and leverage.

In the case of Brazil, the last sharpest drop in the Gross Domestic Product (GDP) occurs in the middle of ex-President Dilma Rousseff's impeachment process. This process begins on December 2, 2015, and ends on August 31, 2016 with the termination of her mandate. In fact, between 2014 and 2015, GDP decreased from $0.50 \%$ to $-3.54 \%$, remaining negative by $-3.30 \%$, between 2015 and 2016 (World Bank, 2021). Thus, economic and political crises are related to each other.

This being so, this study has the objective of identifying the determinants of the dividend payout policy, in the period before (2011-2014) and after (20152018) the former President Dilma Rousseffs impeachment, by means of logarithmic (logit) and probabilistic (probit) regression models. For this purpose, a sample of the Brazilian non-financial companies is considered, whose data are obtained from the Capital IQ base. Capital IQ is a worldwide database of Standard \& Poor's (S\&P), providing financial statement data, ratings, and market indices for more than 135 billion data points.

In spite of the fact that research on the dividend payout in Brazil theme is recent-starting only in 1990 (Martins \& Famá, 2012) - this study differs from the others in that it analyzes the relationship between decisions on dividend payout and market conditions, whether in times of stability or political and economic crisis. This fact is fundamental in the projection of results by both shareholders and companies. For the capital market is important to be aware of alternatives 
for mitigating informational asymmetry, since a payout event provides clues that make shareholders reflect on the company's capacity to generate value.

\section{Literature Review}

The Brazilian Republic Proclamation takes place in 1889. Since then, its democratic track has been interrupted several times. The first election, after the military period beginning in 1964, takes place in 1985. However, the full reestablishment of the democratic process only takes place in 1988, when the current federal constitution was promulgated. Since then, two ex-Presidents have undergone impeachment processes-Fernando Collor de Mello (1992) and Dilma Rousseff (2016). Both are involved in corruption processes. In the case of Dilma Rousseff, the main argument for her removal from the presidency is the disregard for the tax liability law, in addition to association with events revealed by the Car Wash operation. In this occasion, the country is going through a moment of political and economic crisis (Goldstein, 2016; Avritzer, 2017; Nunes \& Melo, 2017; Rocha, 2019; Tran, 2020).

The political crisis of Dilma Rousseff s government is related to two main features: 1) collapse of the presidential coalition system associated with the rise of a conservative group in the national Congress, and 2) crisis of representation expressed by the increase in illegal campaign financing and the influence of the money at the Congress (Avritzer, 2017). Despite Brazil's fast recovery from the contagion effect of the last global financial crisis, the years $2015(-3.55 \%)$ and $2016(-3.31 \%)$ show the worst GDP growth in the last 20 years (World Bank, 2021). According to Barbosa Filho (2017), in her government there is an exemption in tax policy and credit expansion-mainly through financings via the Brazilian Development Bank (BNDES). The state takes an expansionist stance with excessive interventionism, adopting a New Economic Matrix (NME) that implies exchange and price control, subsidies, greater tolerance for inflation, among other aspects. The adoption of the NME reduced the productivity of the Brazilian economy, bringing negative long-term consequences, due to bad investments in low-productive sectors.

The relationship between politics and economics is the subject of a long discussion. The uncertainty arising from changes in government brings real implications for companies. Ranajee et al. (2018) find that the dividend payout policy varies due to an environment of uncertainty resulting from external changes. For Latham and Braun (2011), economic crises are the most transformative events faced by organizations. According to Lim (2016), crises cause reduction in dividend payout and leverage of companies. For Attig et al. (2021), the economic policy uncertainty increases the dividend payout, which fulfills the role of mitigating agency problems on these occasions.

Unlike Miller \& Modigliani (1961), Lintner (1962) and Gordon (1963) state that dividends are relevant. For them, the company's share price is not independent on the dividend payout ratio. Managers choose, on a recurring basis, to 
keep companies' dividend payout policy, even if it means using extra struggle, because this is preferable than cutting or reducing dividends. Ross (1977) argues that this corporate behavior stems from the fact that managers have privileged information in relation to external shareholders. Thus, the definition of a capital structure signals anticipations about the company's results to the market.

Stiglitz (1973) and Myers and Majluf (1984) complement the explanation of the signaling effect and of the pecking order theory (POT) on dividend payout policy. According to the authors, the dividend payout is directly proportional to the estimate that managers make about the value of the company's assets. Thus, decisions about profit distribution through dividends may be seen as a way of reducing information asymmetry between shareholders and managers. Therefore, a payout event provides evidence that leads shareholders to reflect on the value generation capacity of a given company. In addition, companies prefer to finance their investments through profit retention, rather than raising funds through external sources. This way, companies with large investment needs have a lower payout ratio.

In turn, Jensen and Meckling (1976) and Jensen (1986) claim that there is a conflict of interest between managers (agents) and shareholders (main). Therefore, excessive free cash flows must be avoided via debt contracting. This way, they believe that, by taking on debts instead of issuing shares, managers are fulfilling their promise to pay out dividends from investments that effectively create value for companies and their shareholders. Rozeff (1982) and Easterbrook (1984) complement this perception, stating that an optimal dividend payout model shall minimize the sum of agency, capital and taxation costs. Furthermore, AlMalkawi (2008) and Mulchandani et al. (2020) verify that the dividend policy may be influenced by both the tax benefit and the bankruptcy risk resulting from the companies' indebtedness level, as provided for in the trade-off theory (TOT).

Lintner (1956) notes that, the corporate dividend policy has a direct relationship with cyclical fluctuations and with the long-term growth trends in the economy. This very conclusion about the connection of the dividend payout policy to the external environment is verified by Ranajee et al. (2018). According to them, if the external environment is not favorable to the company's operational activities, maintaining a strict dividend payout policy may lead the company to bankruptcy. In turn, Lim (2016) sees a reduction in companies' dividend payout during the last global financial crisis - which began in 2007 in the United States. In view of the above, the hypothesis is: $\mathrm{H} 1-$ The corporate dividend policy is affected by the market situation.

According to Mubin et al. (2014), in line with POT, the larger the company's size, the greater its ability to access external capital sources. In fact, Fama and French (2001) find that the paying companies are larger than the non-paying dividends ones. Therefore, there is a positive relationship between size and dividend payout. For Al-Malkawi (2008) and Mubin et al. (2014), a priori, the debt tax benefit increases the potential for dividend payout, as provided for in TOT. 
However, financial leverage also increases the pressure on the company's cash. Failure to pay principal and debts may lead it to bankruptcy. Thus, the risk arising from high leverage levels reduces dividend payout. Companies need to prioritize their cash with the debt payment. This being so, there is a negative relationship between leverage and dividend payout.

Since the seminal papers by Lintner (1956) and Gordon (1963), the existence of profit is the generating fact for dividend payout, there being, therefore, a positive relationship between both. For Fama and French (2001), Al-Malkawi (2008) and Mubin et al. (2014), POT predicts in its financing sources hierarchy that internal resources (operating cash flow) are cheaper than external ones (debt and equity). As such, companies with lower operating results have less availability to pay for higher debt and equity costs. On the other hand, more profitable companies generate more internal operating results and have more options to make investments with greater profitability, raising the dividend payout level. Therefore, there is a positive relationship between profitability and dividend payout.

According to Ferreira and Vilela (2004), among the benefits of cash retention, there is the minimization of costs for raising external resources, since net assets are seen as a buffer between internal and external capital sources. Yet, cash maintenance costs refer to their low return. In addition, a company paying out dividends may obtain resources at low cost, by reducing its payment-the retained cash can be reinvested in the company's assets with no need for external funding. On the contrary, a company that does not distribute dividendstherefore, does not have the option of retaining cash-needs to obtain funds via capital market or financial institutions for its investment decisions. Therefore, a negative relationship between liquidity and dividend payout is expected.

In turn, De Angelo et al. (2006) state that more mature companies have fewer investment opportunities, therefore, they pay out more dividends. Younger companies, on the contrary, have greater opportunities to invest. Thus, they need to retain more cash and distribute less capital, the cost of which is lower, according to the life cycle theory and POT. Fama and French (2001) observe two groups of companies-those that pay and those that do not pay dividends. Those that don't pay have low profitability; however, they have more growth opportunities via investments. Those who pay have the opposite situation. Thus, there is a negative relationship between growth opportunity and dividend payout. This set of internal attributes gives rise to: $\mathrm{H} 2-$ The corporate dividend policy is affected by the companies' characteristics.

According to Ranajee et al. (2018), if the external environment is not favorable to the maintenance of the company's dividend payout policy, the insistence on its continuity may lead it to bankruptcy. As for Lim (2016), after the last systemic financial crisis-which started in 2007 in the United States-companies reduce their dividend payout, being resilient to the deterioration of the external environment. Rhee and Park (2018) also find greater smoothing in dividend payout after the last global financial crisis. For them, the speed of adjustment in the companies' dividend payout policy increases after the crisis, above pre-crisis 
levels, indicating a greater concentration on investments and cash reserves.

Ankudinov and Lebedev (2016) find that, after the referred crisis, the companies that most reduce their dividend payout are those with the highest leverage level, the greatest investment opportunities and cash restriction or low liquidity. In other words, companies that are more sensitive to capturing external funds, further reduce their dividend payout in times of crisis. Ranajee et al. (2018) also note the difficulty for smaller companies to capture debt and stocks in times of crisis, due to their greater informational asymmetry. Thus, larger companies pay more dividends in this scenario. Thus, for smaller companies, restriction to external financing sources reduces their investment and growth opportunities. In addition, even though profitability is lower in an adverse scenario, it still maintains a positive relationship with dividend payout.

Lim (2016) confirms the dividend payout decrease after the last financial crisis. This crisis reduces the companies' profitability and, consequently, their free cash flow, which causes changes in dividend policy. However, contrary to what is expected by TOT, he identifies a positive relationship between leverage and dividend payout, which confirms the behavior predicted in POT. Finally, Che et al. (2018) also confirm the reduction in dividend payout after the crisis. However, they find that companies with great growth opportunities are more likely to resume dividend payout within 5 years after its cut. The aspects presented support: H3-The corporate dividend policy is affected by its characteristics, which vary depending on the market situation.

The empirical revision of literature has the purpose to highlight the results of similiar studies. In Table 1, the binary dependent variable is the dividend payout. The description of the variables is shown in Table 2. Table 1 points that there is a lack of studies on dividend payout policy considering economic and/or political crisis (CRI) as an independent variable-none of them perform this analysis. The predominance of the logit model is also highlighted, to detriment of the probit one.

In most studies, the determinants of the dividend payout policy are statistically significant and their signs are according to financial theories. POT predicts that there is a hierarchy at the financing sources-internal resources (operating cash flow) are cheaper than external ones (debt and equity). Thus, the larger the company's size (SIZE), the greater its potential of issuing equity and paying dividends. Besides, more profitable (PROF) companies generate more internal operating results and have more options to make investments with greater profitability, raising the dividend payout level. However, companies that pay dividends have less growth opportunities (GROP) via investments. About leverage (LEV), the debt tax benefit increases the potential for dividend payout, according to TOT. However, financial leverage also increases the pressure on the company's cash. Thus, the risk arising from high leverage levels reduces dividend payout. 
Table 1. Synthesis of the results of regression studies with binary dependent variable.

\begin{tabular}{|c|c|c|c|c|c|c|c|c|c|c|c|c|}
\hline \multirow{3}{*}{ Variables } & \multirow{3}{*}{ Theories } & \multirow{3}{*}{ ES } & \multicolumn{2}{|c|}{$\begin{array}{l}\text { Al-Malkawi } \\
\text { (2008) }\end{array}$} & \multicolumn{2}{|c|}{$\begin{array}{l}\text { Tran } \\
\text { et al. (2017) }\end{array}$} & \multicolumn{2}{|c|}{$\begin{array}{c}\text { Ranajee } \\
\text { et al. (2018) }\end{array}$} & \multicolumn{2}{|c|}{$\begin{array}{l}\text { Che et al. } \\
\text { (2018) }\end{array}$} & \multicolumn{2}{|c|}{$\begin{array}{c}\text { Dewasiri } \\
\text { et al. (2019) }\end{array}$} \\
\hline & & & Mod & PRO & Mod & LOG & Mod & LOG & Mod & LOG & Mod & LOG \\
\hline & & & Sign & SIG & Sign & SIG & Sign & SIG & Sign & SIG & Sign & SIG \\
\hline CRI & SI/IA & - & $\mathrm{n} / \mathrm{a}$ & $\mathrm{n} / \mathrm{a}$ & $\mathrm{n} / \mathrm{a}$ & $\mathrm{n} / \mathrm{a}$ & $\mathrm{n} / \mathrm{a}$ & $\mathrm{n} / \mathrm{a}$ & $\mathrm{n} / \mathrm{a}$ & $\mathrm{n} / \mathrm{a}$ & $\mathrm{n} / \mathrm{a}$ & $\mathrm{n} / \mathrm{a}$ \\
\hline SIZE & POT & + & + & $1 \%$ & + & $1 \%$ & + & $1 \%$ & - & $\mathrm{ns} / \mathrm{s}$ & $\mathrm{n} / \mathrm{a}$ & $\mathrm{n} / \mathrm{a}$ \\
\hline LEV & TOT & - & - & $1 \%$ & - & $\mathrm{ns} / \mathrm{s}$ & - & $1 \%$ & - & $\mathrm{ns} / \mathrm{s}$ & $\mathrm{n} / \mathrm{a}$ & $\mathrm{n} / \mathrm{a}$ \\
\hline PROF & POT & + & + & $1 \%$ & + & $1 \%$ & + & $10 \%$ & - & $10 \%$ & + & $5 \%$ \\
\hline LIQ & TOT & - & $\mathrm{n} / \mathrm{a}$ & $\mathrm{n} / \mathrm{a}$ & - & $1 \%$ & + & $1 \%$ & - & $\mathrm{ns} / \mathrm{s}$ & + & $5 \%$ \\
\hline GROP & $\mathrm{POT} / \mathrm{LC}$ & - & + & $\mathrm{ns} / \mathrm{s}$ & - & $1 \%$ & $\mathrm{n} / \mathrm{a}$ & $\mathrm{n} / \mathrm{a}$ & + & $10 \%$ & - & $5 \%$ \\
\hline $\mathrm{CRI}^{*} \mathrm{SIZE}$ & POT & + & $\mathrm{n} / \mathrm{a}$ & $\mathrm{n} / \mathrm{a}$ & - & $\mathrm{ns} / \mathrm{s}$ & $\mathrm{n} / \mathrm{a}$ & $\mathrm{n} / \mathrm{a}$ & $\mathrm{n} / \mathrm{a}$ & $\mathrm{n} / \mathrm{a}$ & $\mathrm{n} / \mathrm{a}$ & $\mathrm{n} / \mathrm{a}$ \\
\hline $\mathrm{CRI}^{*} \mathrm{LEV}$ & TOT & - & $\mathrm{n} / \mathrm{a}$ & $\mathrm{n} / \mathrm{a}$ & - & $\mathrm{ns} / \mathrm{s}$ & $\mathrm{n} / \mathrm{a}$ & $\mathrm{n} / \mathrm{a}$ & $\mathrm{n} / \mathrm{a}$ & $\mathrm{n} / \mathrm{a}$ & $\mathrm{n} / \mathrm{a}$ & $\mathrm{n} / \mathrm{a}$ \\
\hline $\mathrm{CRI}^{*} \mathrm{PROF}$ & POT & + & $\mathrm{n} / \mathrm{a}$ & $\mathrm{n} / \mathrm{a}$ & + & $5 \%$ & $\mathrm{n} / \mathrm{a}$ & $\mathrm{n} / \mathrm{a}$ & $\mathrm{n} / \mathrm{a}$ & $\mathrm{n} / \mathrm{a}$ & $\mathrm{n} / \mathrm{a}$ & $\mathrm{n} / \mathrm{a}$ \\
\hline $\mathrm{CRI}^{\star} \mathrm{LIQ}$ & TOT & - & $\mathrm{n} / \mathrm{a}$ & $\mathrm{n} / \mathrm{a}$ & + & $1 \%$ & $\mathrm{n} / \mathrm{a}$ & $\mathrm{n} / \mathrm{a}$ & $\mathrm{n} / \mathrm{a}$ & $\mathrm{n} / \mathrm{a}$ & $\mathrm{n} / \mathrm{a}$ & $\mathrm{n} / \mathrm{a}$ \\
\hline
\end{tabular}

Notes: ES = Expected sign; Mod = Model; PROB = Probit; LOG = Logit; SIG = Statistical significance level; $\mathrm{SI}=$ Signaling; IA = Informational asymmetry; POT = Pecking order theory; TOT = Trade off theory; LC = Companies' life cycle; AGE = Agency; $n s / s=$ Not statistically significant; $n / a=$ Not applicable.

Table 2. Description of the regression model variables.

\begin{tabular}{|c|c|c|c|c|c|c|}
\hline Acronyms & Variable & Type & ES & Theory & Formula & Variables \\
\hline DIV & $\begin{array}{l}\text { Dummy for } \\
\text { Dividend } \\
\text { payout } \\
\text { ratio (a) }\end{array}$ & $\mathrm{D}$ & $\mathrm{n} / \mathrm{a}$ & $\mathrm{n} / \mathrm{a}$ & $\mathrm{DIV}=\mathrm{DP} / \mathrm{NP}$ & $\begin{array}{c}\mathrm{DP}=\text { Total dividends paid } \\
\mathrm{NP}=\text { Net profit } \\
\text { DUMDIV } \\
0 \text { if }<\text { median DIV } \\
1 \text { if } \geq \text { median DIV }\end{array}$ \\
\hline CRI & Crisis & I & - & SI/IA & $\begin{array}{l}\text { Dummy } \\
\text { for crisis }\end{array}$ & $\begin{array}{c}0=\text { if the period is between } \\
2011 \text { and } 2014 \\
1=\text { if the period is between } \\
2015 \text { and } 2018\end{array}$ \\
\hline SIZE & Size & I & + & POT & $\mathrm{SIZE}=\mathrm{Nl}(\mathrm{TA})$ & $\begin{array}{c}\mathrm{Nl}=\text { Neperian logarithm } \\
\mathrm{TA}=\text { Total assets }\end{array}$ \\
\hline LEV & Leverage & I & - & TOT & $\mathrm{LEV}=\mathrm{TD} / \mathrm{TA}$ & $\begin{array}{c}\mathrm{TD}=\text { Total short and } \\
\text { longterm debt } \\
\mathrm{TA}=\text { Total assets }\end{array}$ \\
\hline PROF & Profitability & I & + & POT & $\mathrm{PROF}=\mathrm{Ebit} / \mathrm{TA}$ & $\begin{array}{c}\text { Ebit = Earnings before } \\
\text { interest and taxes } \\
\text { TA = Total assets }\end{array}$ \\
\hline LIQ & Liquidity & I & - & TOT & $\begin{array}{c}\mathrm{LIQ}=(\mathrm{CA}- \\
\mathrm{CL}) / \mathrm{TA}\end{array}$ & $\begin{array}{c}\mathrm{CA}=\text { Current assets } \\
\mathrm{CL}=\text { Current liabilities } \\
\mathrm{TA}=\text { Total assets }\end{array}$ \\
\hline GROP & $\begin{array}{c}\text { Growth } \\
\text { opportunity }\end{array}$ & I & - & $\mathrm{POT} / \mathrm{LC}$ & $\mathrm{GROP}=\mathrm{MV} / \mathrm{EQ}$ & $\begin{array}{c}\mathrm{MV}=\text { Equity market value } \\
=\text { quantity } \times \text { share price } \\
\mathrm{EQ}=\text { Equity }\end{array}$ \\
\hline
\end{tabular}

Notes: ES = Expected sign; Mod = Model; PROB = Probit; LOG = Logit; SIG = Statistical significance level; $\mathrm{SI}=$ Signaling; IA = Informational asymmetry; POT = Pecking order theory; TOT = Trade off theory; LC = Companies' life cycle; AGE = Agency; ns/s = Not statistically significant; $n / a$ = Not applicable. 


\section{Methodology}

The population of interest consists of non-financial companies listed in Brazil Stock Exchange and Over-the-Counter Market (B3). The initial sample consists of 197 companies. From these, 94 are excluded, since they have not published data for 3 or more years, do not present information on dividend payout or they have losses. This way, the final sample is composed of 103 companies, which are mainly related to the following industries: energy, materials, industrials and utilities.

Their data are obtained from the Capital IQ database, considering the period before (2011-2014) and after (2015-2018) the beginning of the former President Dilma Rousseff's impeachment process. The objectives and hypotheses of this study are verified through descriptive statistics, correlation analysis, and regression with a binary dependent variable - probit and logit.

The probabilistic regression model is a type of regression in which the dependent variable can take only two values ( 0 or 1$)$. The main objective of the model is to estimate the probability or disposition in relation to the decision to be taken. It turns out that this disposition is not observable-latent variable. However, the individual's decision is observed (Bliss, 1935; Stock \& Watson, 2018). The probit coefficients are estimated through the maximum likelihood method. They are consistent and normally distributed over large samples. Among the premises of the probit model are: 1) linear relationship between the vector of the explanatory variables and the dependent variable, 2) expected value of the residuals equal to zero, 3) absence of heteroscedasticity of the residuals, and 4) absence of high multicollinearity between the explanatory variables (Stock \& Watson, 2018; Wooldridge, 2019).

The adjustment quality of the probit model may be assessed in two ways-via determination pseudo coefficient $\left(\mathrm{R}^{2}\right)$ and predictive accuracy. According to Hair et al. (2009), the basic measure of how well the maximum likelihood estimation procedure fits is the likelihood value, being similar to the sums of the squares used in multiple regressions. These adjustment measures are: 1) Likelihood value, 2) Pseudo $\left.R^{2}, 3\right)$ Cox \& Snell $R^{2}$, 4) Nagelkerke $R^{2}$, 5) Hosmer-Lemeshow goodness-of-fit test and f) Chi-square test $\left(\chi^{2}\right)$.

The logistic regression model is similar to the probit one, except for the replacement of the standard normal cumulative distribution function by the standard logistic cumulative distribution function (Stock \& Watson, 2018). As well as the coefficients of the probit model, those of the logit are better interpreted by calculating the predicted probabilities and the differences among them, and they can also be estimated by maximum likelihood. According to Stock and Watson (2018), the main reason for using logit regression is that the logistic cumulative distribution function can be calculated faster than the normal cumulative distribution function.

For Wooldridge (2019) and Hair et al. (2009), the assumption tests, as well as the general measures or statistics of logit model fit quality are the same as those 
of the probit model. The specific statistics for each variable may be analyzed through the Wald Test. The purpose of this test is to check whether a given coefficient is null, including the one of the constant. Its interpretation is similar to the $\mathrm{F}$ or $\mathrm{t}$ values used for the regression significance test.

The regression model of this study is described in Equation 1, and its variables are shown in Table 2. Those companies with a payout ratio (DIV) equal to or above its median (0.3764) are considered to have a high probability of dividend payout-See Table 2.

$$
\text { DIV }=\alpha+\beta \text { Crisis }+\sum \theta \text { Determinants }+\sum \lambda \text { Determinants } * \text { Crisis }+\varepsilon
$$

In which: DIV = payout ratio; Determinants $=$ independent variables; $\alpha=1 \mathrm{i}-$ near coefficient; $\beta, \theta$ e $\lambda=$ angular coefficients; $\varepsilon=$ error term.

\section{Analysis of the Results}

Table 3 presents the descriptive statistics results of the continuous variables mentioned in Table 2. Most of them have 824 observations, corresponding to data from 103 companies for each of the eight years (2011-2018) of the sample. The only exception concerns the growth opportunity variable (GROP). It has 774 observations, since there are companies that go public after a certain year or that do not trade their shares in a specific period.

On average, the companies' payout ratio (DIV) is $57 \%$, which indicates a dividend payout above the mandatory minimum (Brasil, 1976). However, a significant variation is highlighted between the minimum (0\%) and maximum (300\%) values. This fact is corroborated by the amplitude of profitability (PROF), whose mean is $9.3 \%$. There are companies having a loss $(-0.38 \%)$ - which does not allow the dividend payout—and others having profits well above the mean (22.5\%)which increases the potential for dividend payout.

As for the companies' indebtedness level (LEV), on average, the total short and long-term debts represent $28.9 \%$ of their total assets. Again, noteworthy is an inconstancy in this profile, as there are those having basically equity $(0.00 \%)$

Table 3. Descriptive statistics.

\begin{tabular}{ccccccc}
\hline Variables & Observations & Mean & Median & Standard Deviation & Minimum & Maximum \\
\hline DIV (a) & 824 & 0.5754 & 0.3764 & 0.5388 & 0.0000 & 3.0000 \\
SIZE (b) & 824 & 3289.66 & 1638.55 & 4031.51 & 65.40 & $17,003.70$ \\
LEV & 824 & 0.2897 & 0.3078 & 0.1602 & 0.0007 & 0.5892 \\
PROF & 824 & 0.0936 & 0.8712 & 0.0521 & -0.0038 & 0.2251 \\
LIQ & 824 & 0.1750 & 0.1491 & 0.1626 & -0.1004 & 0.5170 \\
GROP & 774 & 2.4774 & 1.7313 & 2.0783 & 0.3133 & 10.2131 \\
Variables & Observations & Mean & Median & Standard Deviation & Minimum & Maximum \\
\hline
\end{tabular}

Notes: For better economic interpretation, (a) the dividend payout index (DIV) is measured as a continuous variable and not as a dummy; (b) the size variable (TAM) refers to the total assets of the companies in millions of dollars (US\$MM), without applying the Neperian logarithm. 
and others with high levels of third-party's capital (58.9\%). This fact may be associated with their liquidity ratio (LIQ). Most companies have current assets higher than their current liabilities, with a mean liquidity of $17.5 \%$. Nevertheless, there are those in which the current liabilities exceed the current assets $(-10.04 \%)$, which represents a greater origin volume than investment of funds in the short term.

Regarding the companies' size (SIZE), on average they have assets of 3289.66 million dollars, which characterize them as large companies (BNDES, 2021). Even so, the sample shows a discrepancy in terms of size, as there are companies with US\$ 65.40 and with US\$17,003.70 million in assets. Finally, the growth opportunity (GROP) indicates that, on average, the companies' market value exceeds their book value by 2.4 times. This fact shows positive perspectives on their future, with a greater expectation of dividend payout. The minimum of 0.31 indicates that the book value of these shares is higher than their quotation on B3. The maximum points to a market value 10.2 times higher than this company's equity.

Table 4 presents the correlation coefficient-and its significance level-of the continuous variables mentioned in Table 2. Regarding the dependent variable, dividend payout ratio (DIV), only liquidity (LIQ) has a sign as expected by TOT. The negative relationship between both variables confirms the fact that companies can reduce their funding costs by reducing the dividend payout. This fact makes them retain more cash, the cost of which is lower than that of resources obtained externally-debts and shares.

Concerning the independent variables, the high positive correlation (56\%) between profitability (PROF) and growth opportunity (GROP) stands out, which may characterize a multicollinearity between both. The construction of these variables infers the existence of a positive relationship between operating results

Table 4. Correlation analysis.

\begin{tabular}{ccccccc}
\hline Variables & DIV & SIZE & LEV & PROF & LIQ & GROP \\
\hline DIV & 1.0000 & & & & & \\
& 0.0524 & 1.0000 & & & & \\
SIZE & $(0.1329)$ & & & & & \\
& 0.0129 & 0.3338 & 1.0000 & & & \\
LEV & $(0.7122)$ & $(\mathbf{0 . 0 0 0 0 )}$ & & & & \\
& 0.0260 & -0.0142 & -0.0733 & 1.0000 & & \\
PROF & $(0.4557)$ & $(0.6842)$ & $(0.0354)$ & & & \\
& -0.1037 & -0.4249 & -0.3545 & -0.1129 & 1.0000 & \\
LIQ & $(0.0029)$ & $(0.0000)$ & $(0.0000)$ & $(0.0012)$ & & \\
& -0.0143 & 0.0220 & -0.0204 & 0.5576 & -0.0215 & 1.0000 \\
GROP & $(0.6912)$ & $(0.5405)$ & $(0.5703)$ & $(0.0000)$ & $(0.5508)$ & \\
\hline
\end{tabular}

Notes: The dividend payout ratio (DIV) is measured as a continuous variable and not in the form of a dummy. In addition, the values in parentheses refer to the significance of the correlation. The values in bold highlight the statistically significant correlations at $1 \%$ or $5 \%$ levels. 
(Ebit) and companies' market value. In turn, liquidity (LIQ) has a negative relationship with size (SIZE), leverage (LEV) and profitability (PROF). Larger companies have more resources invested in long-term assets. In addition, the POT points to a hierarchy in fundraising sources, which characterizes the prioritization of one over the other. Thus, companies having more internal cash flow are less leveraged.

Table 5 shows the results of the logistic regression of the variables mentioned in Equation 1. The regression model presents statistic significance $\left(\mathrm{Prob}>\mathrm{chi}^{2}=\right.$ 0.0000). Furthermore, the independent variables can explain $4.2 \%$ of the dividend payout probability. The crisis dummy variable (CRI), despite having a negative sign, has no statistical significance, which does not allow confirming $\mathrm{H} 1-$ The corporate dividend policy is affected by the market situation. However, there is statistical significance and conformity of the coefficient signs of the variables size (SIZE), profitability (PROF) and liquidity (LIQ) with the theories supporting them.

With regard to size (SIZE), the positive result confirms the POT and is in accordance with the results obtained in the studies by Al-Malkawi (2008); Tran et al. (2017) and Ranajee et al. (2018) — the larger the company's size, the greater the dividend payout probability. As for profitability (PROF), there is a positive coefficient of 5.71, meaning that the Neperian logarithm of the chances increases by 5.71 for each additional profitability percentage. Regarding liquidity (LIQ),

Table 5. Logistic regression.

\begin{tabular}{|c|c|c|c|c|}
\hline \multicolumn{2}{|c|}{$\begin{array}{c}\text { Interaction } 0: \log \text { likelihood }=-536.48558 \\
\text { Interaction 1: } \log \text { likelihood }=-514.01842 \\
\text { Interaction 2: } \log \text { likelihood }=-513.95203 \\
\text { Interaction 3: } \log \text { likelihood }=-513.95202 \\
\text { Logistic regression } \\
\text { Log likelihood }=-513.95202\end{array}$} & \multicolumn{3}{|c|}{$\begin{array}{c}\text { Number of obs }=774 \\
\text { LR chi2 }(11)=45.07 \\
\text { Prob }>\text { chi } 2=0.0000 \\
\text { Log likelihood }=-513.95202 \\
\text { Pseudo } R^{2}=0.0420\end{array}$} \\
\hline DIV Dummy & Coefficients & Odds ratio & $\mathrm{z}$ & $P>|\mathrm{z}|$ \\
\hline CRI & -0.0557 & 0.9458 & -0.05 & 0.959 \\
\hline SIZE & 0.1984 & 1.2195 & 2.04 & $0.041^{\star *}$ \\
\hline LEV & -0.6858 & 0.5037 & -0.90 & 0.370 \\
\hline PROF & 5.7150 & 303.3942 & 2.33 & $0.020^{\star *}$ \\
\hline LIQ & -2.2136 & 0.1093 & -2.76 & $0.006^{* * *}$ \\
\hline GROP & 0.0247 & 1.0250 & 0.41 & 0.680 \\
\hline $\mathrm{SIZE}^{*} \mathrm{CRI}$ & -0.0545 & 0.9469 & -0.43 & 0.669 \\
\hline $\mathrm{LEV}^{\star}{ }^{*} \mathrm{CRI}$ & 0.4781 & 1.6130 & 0.46 & 0.642 \\
\hline $\mathrm{PROF}^{*} \mathrm{CRI}$ & -0.2033 & 0.8160 & -0.06 & 0.955 \\
\hline $\mathrm{LIQ}^{\star}$ CRI & 2.1407 & 8.5052 & 1.96 & $0.051^{\star}$ \\
\hline $\mathrm{GROP}^{*} \mathrm{CRI}$ & -0.0195 & 0.9807 & -0.22 & 0.822 \\
\hline _cons & -1.4328 & 0.2386 & -1.74 & 0.081 \\
\hline
\end{tabular}

Notes: Statistically significant variables at the levels of $1 \%\left(^{\star * *}\right), 5 \%\left({ }^{* *}\right)$ and $10 \%\left({ }^{* *}\right)$. 
the negative sign supports TOT and is in agreement with the study by Tran et al. (2017). Companies paying dividends have less cash than those not paying. Such results confirm $\mathrm{H} 2$ - The corporate dividend policy is affected by the companies' characteristics.

Although the crisis variable (CRI) is not statistically significant, its interaction with liquidity (CRI ${ }^{*} \mathrm{LIQ}$ ) is significant at the $10 \%$ level. The sign of the coefficient contradicts TOT; however, it is in line with the study by Tran et al. (2017). According to TOT, reducing dividend payments is a defensive measure in a period of financial distress. On the other hand, managers tend to use cash to pay out dividends in order to mitigate agency and informational asymmetry problems, which may justify the positive relationship obtained. This result allows confirming $\mathrm{H} 3$ - The corporate dividend policy is affected by its characteristics, which vary depending on the market situation.

Another measure capturing the model fit quality is the Hosmer-Lemeshow goodness-of-fit test. The better the adherence of the estimated probabilities to the groups' a priori classification, the greater the goodness of fit of the model. The test result shows a Prob $>\mathrm{chi}^{2}=0.3533$, which allows the non-rejection of H0: the predicted group classifications are equal to those observed. Table 6 shows the model's correctness level. From a total of 774 observations, 389 (385) point to high (low) probability of dividend payout. Of these, the model has a hit percentage of $61.95 \%$ (241/389) for high probability and $57.40 \%(221 / 385)$ for low probability. Overall, the correctness level of the model is 59.69\% [(241+ 221)/774].

Table 7 presents the results of the probabilistic regression model. Similar to the logit one, the model is significant $\left(\right.$ Prob $\left.>\mathrm{chi}^{2}=0.0000\right)$ and has a similar

Table 6. Logistic model classification.

\begin{tabular}{|c|c|c|c|}
\hline Classified & $\mathrm{D}($ Dummy $=1)$ & $\sim \mathrm{D}($ Dummy $=0)$ & Total \\
\hline+ & 241 & 164 & 405 \\
\hline- & 148 & 221 & 369 \\
\hline Total & 389 & 385 & 774 \\
\hline \multicolumn{4}{|c|}{$\begin{array}{c}\text { Classified }+ \text { if predicted } \operatorname{Pr}(\mathrm{D}) \geq 0.5 \\
\text { True D defined as DUMDI! }=0\end{array}$} \\
\hline Sensitivity & $\operatorname{Pr}(+\mid D)$ & $61.95 \%$ & \\
\hline Specificity & $\operatorname{Pr}(-\mid \sim \mathrm{D})$ & $57.40 \%$ & \\
\hline Positive predictive value & $\operatorname{Pr}(\mathrm{D} \mid+)$ & $59.51 \%$ & \\
\hline Negative predictive value & $\operatorname{Pr}(\sim \mathrm{D} \mid-)$ & $59.89 \%$ & \\
\hline False + rate for true $\sim \mathrm{D}$ & $\operatorname{Pr}(+\mid \sim D)$ & $42.60 \%$ & \\
\hline False - rate for true D & $\operatorname{Pr}(-\mid D)$ & $38.05 \%$ & \\
\hline False + rate for classified + & $\operatorname{Pr}(\sim \mathrm{D} \mid+)$ & $40.49 \%$ & \\
\hline False - rate for classified - & $\operatorname{Pr}(\mathrm{D} \mid-)$ & $40.11 \%$ & \\
\hline Correctly classified & & $59.69 \%$ & \\
\hline
\end{tabular}


Table 7. Probabilistic regression.

\begin{tabular}{|c|c|c|c|c|}
\hline \multicolumn{2}{|c|}{$\begin{array}{c}\text { Interaction 0: } \log \text { likelihood }=-536.48558 \\
\text { Interaction 1: } \log \text { likelihood }=-514.10343 \\
\text { Interaction 2: } \log \text { likelihood }=-514.03721 \\
\text { Interaction 3: } \log \text { likelihood }=-514.0372 \\
\text { Probit regression } \\
\text { Log likelihood }=-514.0372\end{array}$} & \multicolumn{3}{|c|}{$\begin{array}{c}\text { Number of obs }=774 \\
\text { LR chi2 }(11)=44.90 \\
\text { Prob }>\text { chi } 2=0.0000 \\
\text { Pseudo } R^{2}=0.0418\end{array}$} \\
\hline DIV Dummy & Coefficients & Odds ratio & $\mathrm{z}$ & $P>|\mathrm{z}|$ \\
\hline CRI & -0.0745 & -0.11 & 0.911 & -0.0745 \\
\hline SIZE & 0.1201 & 2.02 & $0.043^{\star \star}$ & 0.1201 \\
\hline LEV & -0.4554 & -0.97 & 0.333 & -0.4554 \\
\hline PROF & 3.3876 & 2.30 & $0.022^{* * *}$ & 3.3876 \\
\hline LIQ & -1.3747 & -2.78 & $0.005^{\star * *}$ & -1.3747 \\
\hline GROP & 0.0183 & 0.50 & 0.617 & 0.0183 \\
\hline $\mathrm{SIZE}^{*} \mathrm{CRI}$ & -0.0308 & -0.39 & 0.695 & -0.0308 \\
\hline $\mathrm{LEV}^{\star} \mathrm{CRI}$ & 0.3160 & 0.50 & 0.619 & 0.3160 \\
\hline $\mathrm{PROF}^{*} \mathrm{CRI}$ & 0.0279 & 0.01 & 0.990 & 0.0279 \\
\hline $\mathrm{LIQ}^{*} \mathrm{CRI}$ & 1.3300 & 1.96 & $0.050^{\star *}$ & 1.3300 \\
\hline $\mathrm{GROP} * \mathrm{CRI}$ & -0.0150 & -0.28 & 0.780 & -0.0150 \\
\hline _cons & -0.8452 & -1.70 & 0.090 & -0.8452 \\
\hline
\end{tabular}

Notes: Statistically significant variables at the levels of $1 \%\left({ }^{* * *}\right), 5 \%\left(^{* *}\right)$ and $10 \%\left(^{(* *)}\right.$.

capacity to explain the independent variables (Pseudo $R^{2}=0.0418$ ). The results of the probit model point to the same statistical significance and sense of relationships with the payout dummy for the variables size (SIZE), profitability (PROF), liquidity (LIQ) and interaction between crisis and liquidity (CRI ${ }^{*}$ LIQ).

As for the goodness of fit of the model, the Pearson or Hosmer-Lemeshow test presents a Prob $>\mathrm{chi}^{2}=0.3603$, which characterizes the non-rejection of the null hypothesis that the predicted group classifications are equal to those observed. As a complement to the Hosmer \& Lemeshow test, the analysis of the classification table is carried out to verify the correctness level of the model. Similar to the logit model, from a total of 774 observations, 389 (385) point to a high (low) probability of dividend payout. Of these, the model has a hit percentage of $62.21 \%(242 / 389)$ for high probability and $56.36 \%(217 / 385)$ for low probability.

Overall, the model correctness level is $59.30 \%[(242+217) / 774]$.

\section{Discussion of the Results}

As a result, $\mathrm{H} 1$ is not confirmed-The corporate dividend policy is affected by the market situation. The negative GDP of the years 2015 and 2016 occurs simultaneously with the impeachment process of the former President Dilma Rousseff. However, at the end of this process, there is a bias change in the market is verified. There is a reversal in the capital market drop, a stabilization of in- 
flation, a country risk reduction, an improvement in the consumer's confidence index, among other positive macroeconomic indicators.

Such facts suggest an association between the political and economic crises. The resolution of one implies the solution of the other. In view of this new scenario and considering the downward trend in interest rates in developed countries, Brazil emerges as an attractive investment option. Therefore, notwithstanding the volatility of the economy in the period before and after the impeachment, companies opt for the stability of their dividend payout policy, with payout ratio averages of $62.4 \%$ between 2011 and 2014 and 58.5\% between 2015 and 2018. These facts confirm the non-statistical significance of the crisis dummy variable (CRI).

As for the other independent variables, size (SIZE), profitability (PROF) and liquidity (LIQ), the statistical significance and adequacy of their expected relationship-according to corporate finance theories-with high and low probabilities of dividend payout are verified. Such facts allow confirming H2-The corporate dividend policy is affected by the companies' characteristics. These results are in line with those obtained by Al-Malkawi (2008), Tran et al. (2017) and Ranajee et al. (2018).

Regarding the interaction variables with the crisis dummy, a statistical significance for LIQ ${ }^{*}$ CRI is observed, which allows confirming H3-The corporate dividend policy is affected by its characteristics, which vary depending on the market situation. The positive sign shown indicates that, the greater the cash, the greater the probability of dividend payout, contradicting TOT. However, this result may be associated with the fact that, the use of cash to pay out dividends mitigates agency conflicts and positively signals the company's financial conditions to the market.

\section{Conclusion}

The issue of determinants of the dividend payout policy has been studied for a long time, due to the relevance of the decisions about the application of companies' profits. It so happens that, in addition to the variables intrinsic to organizations, there are other exogenous ones that equally impact their payout ratio. Among them, economic and political crises stand out. These events have become increasingly frequent as a result of greater access to information and integration of the markets. In the case of Brazil, the last sharpest drop in GDP-before the COVID-19 world pandemic-takes place in the midst of the former President Dilma Rousseff's impeachment process. The confluence between both political and economic crises culminate in the termination of her mandate on August 31, 2016.

In view of the above, this study aims at identifying the determinants of the dividend payout policy, in the period before (2011-2014) and after (2015-2018) the former President Dilma Rousseff's impeachment. For such, a logarithmic and probabilistic regression model is applied from a sample of 103 non-financial 
companies listed on B3. Data are obtained from the Capital IQ base, between the years 2011 and 2018.

The results of the study do not confirm H1-The corporate dividend policy is affected by the market situation. The non-statistical significance of the crisis dummy variable indicates that Brazilian companies choose to maintain their dividend payout policy. However, there is confirmation of hypothesis H2-The corporate dividend policy is affected by the companies' characteristics, and H3The corporate dividend policy is affected by its characteristics, which vary depending on the market situation.

The main limitation of this study refers to the lack of companies' market value for some periods, which reduces the number of observations of the growth opportunity variable (GROP), from 824 to 774 . In addition, there are sectors being more or less sensitive to economic and political changes. Nonetheless, in the case of Brazil, considering this variable it is not feasible, due to the limited number of publicly traded companies for certain segments.

For the evolution of the theme presented, the analysis of the impact of other types of crisis on the companies' dividend payout policy is suggested. These crises may be of a political or sanitary nature-such as the COVID-19 pandemic. In order to control their effects on the economy, to consider macroeconomic control variables is recommended, such as GDP, inflation and unemployment rate.

\section{Conflicts of Interest}

The authors declare no conflicts of interest regarding the publication of this paper.

\section{References}

Al-Malkawi, H.-A. N. (2008). Factors Influencing Corporate Dividend Decision: Evidence from Jordanian Panel Data. International Journal of Business, 13, 177-195.

Ankudinov, A. B., \& Lebedev, O. V. (2016). Dividend Payouts and Company Ownership Structure amid the Global Financial Crisis: Evidence from Russia. Journal of PostCommunist Economies, 28, 384-404. https://doi.org/10.1080/14631377.2016.1196882

Attig, N., Ghoul, S. E., Guedhami, O., \& Zheng, X. (2021). Dividends and Economic Policy Uncertainty: International Evidence. Journal of Corporate Finance, 66, 1-28. https://doi.org/10.1016/j.jcorpfin.2020.101785

Avritzer, L. (2017). The Rousseff Impeachment and the Crisis of Democracy in Brazil. Critical Policy Studies, 11, 352-357. https://doi.org/10.1080/19460171.2017.1363066

Barbosa Filho, F. H. (2017). The Economic Crisis of 2014/2017. Estudos Avançados, 31, 51-60. https://doi.org/10.1590/s0103-40142017.31890006

Barros, V., Matos, P. V., \& Sarmento, J. M. (2020). What Firm's Characteristics Drive the Dividend Policy? A Mixed-Method Study on the Euronext Stock Exchange. Journal of Business Research, 115, 365-377. https://doi.org/10.1016/j.jbusres.2019.11.042

Bliss, C. I. (1935). The Calculation of the Dosage-Mortality Curve. Annals of Applied Biology, 22, 134-167. https://doi.org/10.1111/j.1744-7348.1935.tb07713.x

Brazilian Development Bank (BNDES) (2021). Company Size. 
https://www.bndes.gov.br/wps/portal/site/home/financiamento/guia/porte-de-empresa

Che, X., Liebenberg, A. P., Liebenberg, I. A., \& Morris, B. C. L. (2018). The Effect of Growth Opportunities on the Market Reaction to Dividend Cuts: Evidence from the 2008 Financial Crisis. Review of Quantitative Finance and Accounting, 51, 1-17. https://doi.org/10.1007/s11156-017-0663-8

De Angelo, H., Deangelo, L., \& Stulz, R. M. (2006). Dividend Policy and the Earned/Contributed Capital Mix: A Test of the Life-Cycle Theory. Journal of Financial Economics, 81, 227-254. https://doi.org/10.1016/j.jfineco.2005.07.005

Dewasiri, N. J., Koralalage, W. B. Y., Azeez, A. A., Jayarathne, P. G. S. A, Kuruppuarachchi, D., \& Weerasinghe, V. A. (2019). Determinants of Dividend Policy: Evidence from an Emerging and Developing Market. Managerial Finance, 45, 413-429.

https://doi.org/10.1108/MF-09-2017-0331

Driver, C., Grosman, A., \& Scaramozzino, P. (2020). Dividend Policy and Investor Pressure. Economic Modelling, 89, 559-576. https://doi.org/10.1016/j.econmod.2019.11.016

Easterbrook, F. H. (1984). Two Agency-Cost Explanations of Dividends. American Economic Review, 74, 650-659.

Fama, E., \& French, K. (2001). Disappearing Dividends: Changing Firm Characteristics or Lower Propensity to Pay? Journal of Applied Corporate Finance, 14, 67-79. https://doi.org/10.1111/j.1745-6622.2001.tb00321.x

Ferreira, M., \& Vilela, A. (2004). Why Do Firms Hold Cash? Evidence from EMU Countries. European Financial Management, 10, 295-319. https://doi.org/10.1111/j.1354-7798.2004.00251.x

Fischer, E. O., Heinkel, R., \& Zechner, J. (1989). Dynamic Capital Structure Choice: Theory and Tests. Journal of Finance, 44, 19-40. https://doi.org/10.1111/j.1540-6261.1989.tb02402.x

Goldstein, A. (2016). La tormenta perfecta: Crisis e impeachment en el segundo mandato de Dilma Rousseff. Análisis Político, 29, 90-104. https://doi.org/10.15446/anpol.v29n88.63639

Gordon, M. J. (1959). Dividends, Earnings and Stock Prices. Review of Economics and Statistics, 41, 99-105. https://doi.org/10.2307/1927792

Gordon, M. J. (1963). Optimal Investment and Financing Policy. Journal of Finance, 28, 264-272. https://doi.org/10.1111/j.1540-6261.1963.tb00722.x

Hair Jr., J. F., Black, W. C., Babin, B. J., \& Anderson, R. E. (2009). Multivariate Data Analysis. Porto Alegre: Bookman.

Jensen, M. C. (1986). Agency Costs of Free Cash Flow, Corporate Finance, and Takeovers. American Economic Review, 76, 323-329. https://www.jstor.org/stable/1818789

Jensen, M. C., \& Meckling, W. H. (1976). Theory of the Firm: Managerial Behavior, Agency Costs and Ownership Structure. Journal of Financial Economics, 3, 305-360. https://doi.org/10.1016/0304-405X(76)90026-X

Kraus, A., \& Litzenberger, R. H. (1973). A State-Preference Model of Optimal Financial Leverage. Journal of Finance, 28, 911-922. https://doi.org/10.1111/j.1540-6261.1973.tb01415.x

Latham, S., \& Braun, M. (2011). Economic Recessions, Strategy, and Performance: A Synthesis. Journal of Strategy and Management, 4, 96-115. https://doi.org/10.1108/17554251111128592

Lim, K. (2016). The Shift of a Dividend Policy and a Leverage Policy during the 2008 Financial Crisis. International Journal of Finance \& Banking Studies, 5, 9-14. 
https://doi.org/10.20525/ijfbs.v5i6.600

Lintner, J. (1956). Distribution of Incomes of Corporations among Dividends, Retained Earnings and Taxes. American Economic Review, 46, 97-113. https://www.jstor.org/stable/1910664

Lintner, J. (1962). Dividends, Earnings, Leverage, Stock Prices and the Supply of Capital to Corporations. Review Economics and Statistics, 4, 243-269. https://doi.org/10.2307/1926397

Martins, A. L., \& Famá, R. (2012). What the Studies Conducted in Brazil Regarding Dividend Policy Reveal? Revista de Administração de Empresas, 52, 24-39. https://doi.org/10.1590/S0034-75902012000100003

Miller, M. H., \& Modigliani, F. (1961). Dividend Policy, Growth, and the Valuation of Shares. Journal of Business, 34, 411-433. https://doi.org/10.1086/294442

Mubin, M., Ahmed, M., Farrukh, M., Lal, I., \& Hussain, A. (2014). Determinants of Dividend with Industry-Wise Effect-Evidence from KSE 100 Index. Research Journal of Finance and Accounting, 5, 62-69.

https://www.iiste.org/Journals/index.php/RJFA/article/view/11021/11322

Mulchandani, K., Mulchandani, K., \& Wasan, P. (2020). Dividends and Earnings Quality: Evidence from India. IIMB Management Review, 32, 166-176.

https://doi.org/10.1016/j.iimb.2019.10.001

Myers, S. C. (1984). The Capital Structure Puzzle. Journal of Finance, 39, 575-592. https://doi.org/10.2307/2327916

Myers, S. C., \& Majluf, N. S. (1984). Corporate Financing and Investment Decision When Firms Have Information Investors Do Not Have. Journal of Financial Economics, 13, 187-221. https://doi.org/10.1016/0304-405X(84)90023-0

Nunes, F., \& Melo, C. R. (2017). Impeachment, Political Crisis and Democracy in Brazil. Revista de Ciência Política, 37, 281-304. https://doi.org/10.4067/s0718-090x2017000200281

Ranajee, R., Pathak, R., \& Saxena, A. (2018). To Pay or Not to Pay: What Matters the Most for Dividend Payments? International Journal of Managerial Finance, 14, 230-244. https://doi.org/10.1108/IJMF-07-2017-0144

Rhee, K., \& Park, K. S. (2018). Changes in Dividend Smoothing after the Financial Crisis. Economic Letters, 172, 37-39. https://doi.org/10.1016/j.econlet.2018.08.019

Rocha, C. (2019). “Taxation Is Theft!”-The Formation of an Ultraliberal Counter-Public and Dilma Rousseff's Pro-Impeachment Protests. Revista de Ciências Sociais, 62, 1-42. https://doi.org/10.1590/001152582019189

Ross, S. A. (1977). The Determination of Financial Structure: The Incentive-Signalling Approach. Bell Journal of Economics, 8, 23-40. https://doi.org/10.2307/3003485

Rozeff, M. S. (1982). Growth, Beta and Agency Costs as Determinants of Dividend Payout Ratios. Journal of Financial Research, 5, 249-259. https://doi.org/10.1111/j.1475-6803.1982.tb00299.x

Stiglitz, J. E. (1973). Taxation, Corporate Financial Policy and the Cost of Capital. Journal of Public Economics, 2, 1-34. https://doi.org/10.1016/0047-2727(73)90008-X

Stock, J. H., \& Watson, M. W. (2018). Introduction to Econometrics. London: Pearson.

Tran, Q. T. (2020). Corruption, Agency Costs and Dividend Policy: International Evidence. Quarterly Review of Economics and Finance, 76, 325-334.

https://doi.org/10.1016/j.qref.2019.09.010

Tran, Q. T., Alphonse, P., \& Nguyen, X. M. (2017). Dividend Policy: Shareholder Rights 
and Creditor Rights under the Impact of the Global Financial Crisis. Economic Modelling, 64, 502-512. https://doi.org/10.1016/j.econmod.2017.03.010

Wooldridge, J. M. (2019). Introductory Econometrics: A Modern Approach. Boston, MA: Cengage Learning.

World Bank (2021). World Development Indicators. GDP Growth (Annual \%). https://databank.worldbank.org/data/source/world-development-indicators 